DOI: $10.7819 /$ rbgn.v15i49.1586

Subject Area: Organizational Strategy and Behavior

\title{
The Influence of the Environment on Organizational Innovation in Service Companies in Peru
}

\author{
Influência do Ambiente na Inovação Organizacional em Empresas \\ Prestadoras de Serviços no Peru
}

\section{Influencia del Entorno en la Innovación Organizacional en Empresas de Servicio en Perú}

\author{
Peter Yamakawa Tsuja ${ }^{1}$ \\ Jhony Ostos Mariño ${ }^{2}$
}

Received on March 13, 2013 / Approved on November 25, 2013

Responsible Editor: João Maurício Gama Boaventura, Dr.

Evaluation Process: Double Blind Review

\begin{abstract}
Several authors consider the environment variable to be an influential element on the innovation variable, but they do not provide further insight of the dimensions of these variables. This study, applied to a sample of service companies, includes dimensions of environment (uncertainty and complexity) and dimensions of innovation (technical and administrative), as well as organizational characteristics as a moderating variable in this relationship between environment and innovation. The results indicate that an uncertain environment promotes only technical innovation, while a complex environment promotes both administrative and technical innovation. It was also found that organizational characteristics partially moderate the relationship between the two variables.
\end{abstract}

Keywords: Environment. Innovation. Organization

\section{RESUMO}

Diversos autores consideram a variável ambiente um elemento influente na variável inovação, mas não aprofundam quanto às dimensôes destas variáveis. Este estudo, realizado em uma amostra de empresas prestadoras de serviços, abrange dimensôes do ambiente (incerteza e complexidade) e da inovação (técnica e administrativa), além das características organizacionais como variável mediadora da relação entre o ambiente e a inovação. Os resultados indicam que o ambiente incerto promove apenas a inovação técnica, ao passo que o ambiente complexo promove tanto a inovação técnica e quanto a administrativa. Este estudo também comprova que as características organizacionais moderam parcialmente a relação entre as duas variáveis.

Palavras-chave: Ambiente. Inovação. Organização.

1. PhD in Engineering from the University of Osaka, Japan. Professor of Universidad ESAN. [pyamakawa@esan.edu.pe]

2. PhD in Management Science from the Ramón Llull University - ESADE, Spain. Professor of Universidad ESAN. [jostos@esan.edu.pe] Authors' address: Alonso de Molina 1652, Monterrico, Surco - Lima, Peru 33 


\section{RESUMEN}

Diversos autores consideran la variable entorno un elemento influyente en la variable innovación, pero no profundizan en las dimensiones de estas variables. Este estudio, realizado en una muestra de empresas de servicio, incluye dimensiones del entorno (incertidumbre y complejidad) y de la innovación (técnica y administrativa), además de las características organizacionales como variable mediadora de la relación entre entorno e innovación. Los resultados indican que el entorno incierto promueve solo la innovación técnica, mientras que el entorno complejo promueve tanto la innovación técnica como la administrativa. También se comprueba que las características organizacionales moderan parcialmente la relación entre ambas variables.

Palabras clave: Entorno. Innovación. Organización.

\section{INTRODUCTION}

The environment is an external factor to the organization, and a direct motivator of changes implementation in the company. It is a key element for the organizational innovation, because its constant changes, on making the management of value and quality of products and/or services difficult, stimulate the creation of new products, new services and new processes, to compete in the marketplace (DAMANPOUR; EVAN, 1984; TUSHMAN; NADLER, 1986). Other authors state that the understanding of the environment contingencies might promote more effective innovation activities (HAN; KIM; SRIVASTAVA, 1998; LI; ATUAHENE-GIMA, 2001; TIDD, 2001). On the other hand, Farjoun (2010) proposes a continuous need of change, innovation and exploration in organizations to that they can remain in the marketplace.

Various authors state that the organizational innovation is expressed in changes of the organization's internal variables in response to the changes in external variables; thus, the innovation activities in organizations have better results when the environment evaluation is more comprehensive. In order to get a deeper idea of the environment behavior, it is necessary to analyze various dimensions of such environment; the investigations on organizational innovation are extensive, but limited by their reach, because they do not properly encompass the large margin of each aspect of the innovation, such as the administrative innovation, Tidd (2001) and Damanpour (1996), innovation studies have historically given priority to the investigation and development, and to technology, to then focus on the innovation of products and services (DAMANPOUR; WALKER; AVELLANEDA, 2009).

The organizational innovation is defined in various ways; it is a process of generation, development and implementation of new ideas (DAMANPOUR, 1996); it is the development and implementation of new ideas within an institutional order (VAN DE VEN, 1986); it is the implementation of new processes, new products and new focus of administration to enhance the efficiency and effectiveness of the company (SEADEN et al., 2003).

In the literature review, innovation is frequently related to organization (WISCHNEVSKY; DAMANPOUR, 2006), but the connection between the organizational characteristics and the types of innovation is ignored. In the design of the organizational structure, five basic configurations are identified: simple structure, mechanical bureaucracy, professional, divisional bureaucracy, and adhocracy, and nine organizational characteristics: specialization of the work, formalization, training, group, size, planning and control, liaison mechanisms, vertical and horizontal decentralization (MINTZBERG, 1980). Out of these organizational characteristics, three are more significant in the decision-making process: centralization, formalization and complexity (FREDRICKSON, 1986), which are used in this work.

The innovation practices in the services sector are developed throughout all the management activities carried out in the company, 
and are less systematic than in the manufacturing sector, because service companies rarely have a research and development (R\&D) department; therefore, it is necessary to expand the study of innovations in service companies to understand other forms of innovation (TOIVONEN, 2010). Resende Junior and Guimaráes (2012) conduct an extensive literature review on service innovation, and state that there is a relative scarcity of empirical studies addressing companies of the public and private sectors.

From this literature review, we can deduce that it is necessary to continue exploring the relations between the environment and the organization's internal variables, specifically the organizational innovation and the organizational characteristics (DAMANPOUR, 1996; 1991; HAN; KIM; SRIVASTAVA, 1998; OLSON; SLATER; HULT, 2005; TIDD, 2001). Thus, the objective of this study is to examine the influence of the environment in the organizational innovation, as well as to analyze the behavior of the organizational characteristics as a moderator variable of this relation.

\section{REVIEW OF LITERATURE}

\section{I Environment}

The environment is an external force which behavior influences the organization, depending on the marketplace where it operates and the technology it uses. The changes of the environment are increasingly fast, and to survive companies should create new products, services and processes (TUSHMAN; NADLER, 1986). The environment behavior translates in new challenges for companies; some of them adopt technology from other companies, while others create their own research and development efforts to be more competitive (BARKEMA; BAUM; MANNIX, 2002). In high demand and sufficient resources' environments of companies, innovation activities are promoted; on the other hand, in low demand and scarce resources' environments, innovation activities are restricted (KATILA; SCOTT, 2005); independent companies provide the necessary ideas to variety of possible innovations, while business groups provide the support infrastructure for the innovation activities (MAHMOOD; MITCHELL, 2004).

Researches associate environment with uncertainty, complexity, dynamism, heterogeneity and turbulence. Duncan (1972), on his part, established two types of environment, which in turn have two dimensions each: a) the simplecomplex environment, which is related to the amount of the environment factors; and b) the static and dynamic environment, which is the degree in which the decision factors of the external environment change. Miller (1991) analyzes the environment under two associations: uncertain environment, which is associated to the predictability of the marketplace changes, and the heterogeneous environment, which is associated to the variety of administrative, production and marketing requirements. Han, Kim and Srivastava (1998) analyze the environment from two aspects: market turbulence, associated to the diversity of consumers' preferences, and technology turbulence, associated to the lack of technological standard of the manufacturing sector. Lee (2010); Olson, Slater and Hult (2005) also analyze the environment from these aspects: a) Market turbulence, which is the customer's preference changing rate; and b) Technology turbulence, which is the new products and processes changing rate, as the result of a technological propagation. Figure 1 shows a summary of the approaches to the environment. 


\begin{tabular}{|l|l|}
\hline Environment dimensions & Authors \\
\hline Uncertain and complex & Tidd (2001) \\
\hline Market turbulence and Technological turbulence & Lee (2010; Olson, Slater and Hult (2005), Han, Kim and Srivastava (1998) \\
\hline Uncertain and heterogeneous & Miller (1991) \\
\hline Simple-Complex and Static-Dynamic & Duncan (1972) \\
\hline
\end{tabular}

FIGURE 1 - Environment dimensions according to authors

Source: the authors

According to the reviewed environment analysis proposals, the authors propose studies and use different names to refer to the dimensions, although all of them have similar meanings. In innovation management studies, Tidd (2001) states that it is better to differentiate two dimensions of the environment: uncertainty and complexity, because these two create different requirements of administrative management; on one hand, the complex environment is defined as the amount of external variables influencing the organization, and, on the other hand, the uncertain environment exists in function of the changing rate of factors that influence the organization. In this study, the dimensions proposed by Tidd (2001) are recognized, while the variables composing each of these dimensions: customers, competitors, and technology, are brought from Jaworski and Kohli (1993).

Another important consideration about the environment is the role played by the government. When a country does not have technology, the government can stimulate the economy through the political and economic control; however, when a country has technology, the government can release the political and economic control (MAHMOOD; RUFIN, 2005). The government can promote innovation activities through selfowned or acquired innovations (HOSKISSON et al., 2002).

\subsection{Organizational innovation}

The organizational innovation is related to the creation and implementation of new ideas (DAMANPOUR, 1996; SEADEN et al., 2003; VAN DE VEN, 1986). With innovation, there is an attempt to enhance efficiency (quality improvement, production cost reduction) and effectiveness (bigger market share, customer satisfaction improvement) of the company (SEADEN et al., 2003).

In the reviewed papers, various types of innovation were found, among them the following: a) radical, which produces key changes in the organization activities; b) incremental, which creates a lower degree change in the organization activities; c) administrative, referred to changes in the organizational structure, the administrative process and the human resources; d) technical, related to the changes in products and services, and technology; e) of products, related to the introduction of new products and services in the marketplace; and f) of processes, which is the introduction of new production processes of goods and services (DAMANPOUR, 1996; DAMANPOUR; ARAVIND, 2012; SHEREMATA, 2004). There is also the type of disruptive innovation, in which the normal flow of products in the market is interrupted (GILBERT, 2003).

There are other types of innovation, such as: a) compatible, b) incompatible, c) incompatibleradical, and d) compatible-incremental, which are adopted depending on the marketplace characteristics and the technology used by the company (SHEREMATA, 2004). There is also the architectural innovation, oriented towards the dynamic capacities to manage resources in new assets according to the marketplace changes (GALUNIC; EISENHARDT, 2001; HENDERSON; CLARK, 1990).

Some studies promote the type of modular innovation for their utility in solving complex problems ((BALDWIN; CLARK, 2000; ETHIRAJ; LEVINTHAL, 2004; PIL; COHEN, 
2006; SCHILLING; STEENSMA, 2001). Figure 2 shows the different types of innovation.

Among the various types of innovation, three classifications are under the spotlight: a) administrative and technical, b) of products and processes, and (c) radical and incremental (DAMANPOUR, 1991). The distinction between administrative innovation and technical innovation is regarded as important in the innovation and structure studies, because it allows better observing the differences between the social system and the technical system of the organization, and in addition because the technical innovations and the administrative innovations are started in different areas of the organization, with their own adoption processes (DAMANPOUR, 1996). Pursuant to this statement, other studies also analyze the organizational innovation, making a distinction between technical innovation and administrative innovation (HAN; KIM; SRIVASTAVA, 1998).

\begin{tabular}{ll}
\hline Types of innovation & Authors \\
\hline Radical e incremental & $\begin{array}{l}\text { Damanpour, Aravind (2011); Sheremata (2004); } \\
\text { Damanpour (1996) }\end{array}$ \\
\hline Products and processes & Damanpour, Aravind (2011); Damanpour (1996) \\
\hline Technical and administrative & $\begin{array}{l}\text { Ussahawanitchakit (2012); Damanpour, Aravind (2011); } \\
\text { Han, Kim \& Srivastava (1998); Damanpour (1996) }\end{array}$ \\
\hline $\begin{array}{l}\text { Compatible, incompatible, incompatible- } \\
\text { radical, compatible-incremental }\end{array}$ & Sheremata (2004) \\
\hline Disruptive & Gilbert (2003) \\
\hline Architectural & Galunic, Eisenhardt (2001); Henderson, Clark (1990) \\
\hline Modular & Ethiraj, Levinthal (2004); Schilling, Steensma (2001); Pil, \\
\hline
\end{tabular}

FIGURE 2 - Types of innovation according to authors

Source: the authors

The implementation of radical innovations supposes overcoming organizational barriers, which implies stimulating the employees' absorption capacity, the elimination of routine actions, fostering the pursuit of ideas, and the exploration of other market niches (HILL; ROTHAERMEL, 2003). The success of radical innovation depends on the corporate culture (TELLIS; PRABHU; CHANDY, 2009).

Other researches focused on the actions prior to the implementation of innovations, because they can cause a different and effective impact (ZHOU; YIM; TSE, 2005). Damanpour and Schneider (2009) found an impact of the innovation characteristics and of the managers' characteristics on the adoption of innovation. Almirall and Casadesus-Manasell (2010) point out that for a better innovation implementation, executives should keep objectives homogeneous.
D'Alvano and Hidalgo (2012) state that consumers are increasingly demanding more, better and more valuable services, and thus organizations need to improve their innovation process in order to develop new solutions. Toivonen (2010) extends the innovation investigation to service companies, analyzing three types of innovation processes: a) Innovation as a project separated from the practice, b) innovation following the fast application model; and c) innovation following the practical management model.

\subsection{Organizational characteristics}

The replacement of old organizational structures by new organizational structures is known as organizational redesign, which includes changes in the organizational characteristics. The organizational transformation is a major 
change including the organizational structure, the distribution of power, and the strategy (WISCHNEVSKY; DAMANPOUR, 2006).

Mintzberg, Quinn and Voyer (1997) propose seven structural configurations: a) Business organization, b) Machine organization, c) Professional organization, d) Diversified organization, e) Innovative organization, f) Missionaire organization, and g) Political organization. In regard to the organizational characteristics, in another paper, Mintzberg (1980) proposes nine of them: a) work specialization, b) formalization, c) training, d) group, e) size, f) planning and control, g) liaison mechanisms, h) vertical decentralization, and i) horizontal decentralization.

The organization structure and characteristics are related to the environment behavior. In a stable environment, the organizational structure can be rigid and have the following organizational characteristics: vertical control, efficiency, specialization, standardization and centralization in the decision-making process; in a quickly changing environment, a more flexible structure is needed, with a strong horizontal coordination, little standardization, and a centralized decision-making process (DAFT, 2004). An uncertain environment keeps a negative relation with the centralization of decisions, and a positive relation with the organic structure; a heterogeneous environment is related to the specialization and to the liaison mechanisms (MILLER, 1991).

In a study on the relations between organizational innovation and thirteen organizational characteristics, Damanpour (1991) found out that ten of such characteristics are associated to innovation: specialization, functional differentiation, management attitudes towards change, professionalism, decentralization, sources of technical knowledge, administrative intensity, inactive resources, and internal and external communication, while the other three are directly associated to innovation: high formalization, centralization of decisions, and vertical differentiation.
Frequently, the association between organizational characteristics and the types of organization is ignored. Nevertheless, three organizational characteristics, centralization, formalization and complexity of tasks, received more attention because they have a stronger influence in strategic decision-making (FREDRICKSON, 1986). A similar analysis of these three organizational characteristics is also found in the studies of Olson, Slater and Hult (2005).

\section{THEORETICAL REFERENCES}

\section{I Relation between the environment and the organizational innovation}

Damanpour (1996) states that innovation is a process of creation and implementation of new ideas in the organization in response to the environment changes. According to the reviewed paper, there is a relation between the environment variables and the organizational innovation, and between each of the different dimensions of such variables; McCrea and Betts (2008) point out that innovations allow companies to get a competitive edge, in addition to becoming more capable of responding to the dynamic environment. Misra, Sharma and Kadar (2011) state that innovation is a key element for the success of organizations, which need to be constantly changing to make use of the opportunities offered by the environment. Semadeni and Anderson (2010) state that the consequences of innovation and imitation in the services sector are still unknown, even more in environments with uncertainty and with a high information asymmetry. Tidd (2001) proposes analyzing the environment dimensions: complexity and uncertainty because both affect the magnitude and the nature of innovation.

In the literature review, we have found various types of innovation; however, for studies including organizational innovation, organizational structure, and organizational performance, Damanpour (1996) recommends to differentiate technical innovation from administrative innovation, because these two 
types of innovation better relate to the social and technical system of the organization. To maintain or improve the performance level, the balanced adoption of an administrative innovation and a technical innovation is more effective in the organization than rather only the implementation of one of them. Technical innovations promote the organizational effectiveness, while the administrative innovations are necessary to obtain a balance between the social structure and the technical system of the organization (DAMANPOUR; SZABAT; EVAN, 1989).

\subsection{Organizational characteristics as moderator variable}

Tidd (2001) states that the best innovation administration practices vary depending on a series of external factors of the company, suggesting the consideration of the organization variable in the analysis of the environment and of the innovation. Also, he states that considering that the environment changes affect the organization behavior, it is better to look for different organizational designs that adapt to such changes. Adams, Bessant and Phelps (2006) state that to create and to transform ideas of products that are usable and tradable in the marketplace, high levels of inter-functional coordination and integration are needed. The innovative organizations have a flexible organizational structure, promote the diversity of opinions, and have specialists instead of generalists to make decisions related to innovation (MISRA; SHARMA; KADAR, 2011).

\section{HYPOTHESIS}

In regard to the relation between the environment and the organizational innovation, Han, Kim and Srivastava (1998), and Li and Atuahene-Gima (2001) state that a bigger uncertainty of the environment promotes a bigger innovation of the company. In regard to the complex environment, $\mathrm{Li}$ and
Atuahene-Gima (2001) state that the effectiveness of product innovation depends on the management perception of the environment complexity.

As for the innovation analysis, according to several authors, the adoption of the organizational innovation takes place through various types of innovation ((DAMANPOUR; SZABAT ; EVAN, 1989; GATIGNON et al., 2002). There are two alternatives to analyze the organizational innovation: evaluate it as a single variable, or independently evaluate each of its dimensions: technical innovation and administrative innovation. Han, Kim and Srivastava (1998) propose to examine the organizational innovation as a single variable, also from each of its dimensions. In view of the aforementioned, the following hypotheses are suggested:

H1: An increase of environment changes generates an increase of the organizational innovation.

H2a: An increase of the environment uncertainty generates an increase of the technical innovation.

H2b: An increase of the environment uncertainty generates an increase of the administrative innovation.

H3a: An increase of the environment complexity generates an increase of the technical innovation.

H3b: An increase of the environment complexity generates an increase of the administrative innovation.

Tidd (2001) proposes to consider the organization variable in the environment and innovation analysis. Thus, other studies examine the organizational characteristics, and relate them to the environment (MILLER, 1987; OLSON; SLATER; HULT, 2005) or to the implementation of innovation practices (DAMANPOUR; EVAN, 1984 ; DECANIO; DIBBLE; AMIR-ATEFI, 2000; KIMBERLY; EVANISKI, 1981). Considering the aforementioned, we propose the following hypotheses:

H4a: The organizational characteristics strengthen the relation between the environment and the technical innovation. 
H4b: The organizational characteristics strengthen the relation between the environment and the administrative innovation.

This study is conducted at the level of dimensions, both for the environment (uncertain and complex), as well as for the organizational innovation (technical and administrative), and the organizational characteristics are included as moderator variable. Figure 3 shows the proposed model.

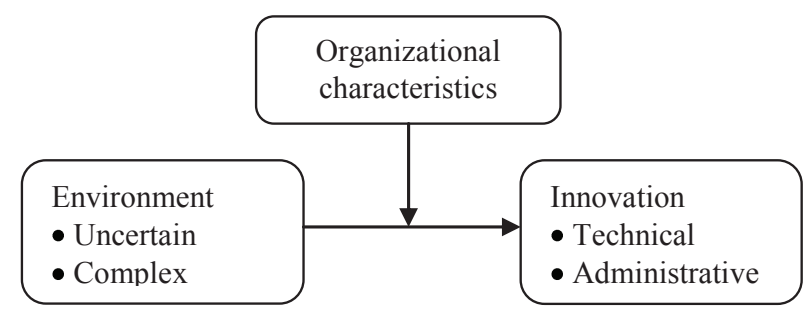

FIGURE 3 - Model proposed in the study

Source: the authors

\section{DESIGN OF THE SURVEY}

\section{I Sample}

The study addresses the analysis of companies from the service sector operating in Lima, Peru, with 50 workers or more. Service companies were selected because this sector employs more than $50 \%$ of the economically active population according to the National Institute of Statistics and Informatics - INEI ([2008]), being an important drive for the Peruvian economy growth, registering an annual average growth rate of more than $6 \%$ in the past seven years - INEI ([2010]), and this trend should be maintained. 2009 was an exception, and in that year the growth rate was reduced as a result of the international crisis. Companies were carefully selected to have 50 workers or more, because the size of the company is very important in innovation studies, in order to prevent distortions in the answers of respondents. Gopalakrishnan (2000) points out that large companies have bigger scale economies in their activities, in comparison to small and micro companies, and such differences are expressed in the employees' perceptions of belonging and valuation.

The sample has 104 companies of the service sector, belonging to the subsectors of banks and insurances, commerce, transports, technology, telecommunications, education, tourism, among others, which operation centers are located in Lima, Peru. Data collection was carried out through a live survey with 192 executives working in different service companies in Lima, Peru. This live survey compilation procedure allowed to evaluate the fitness of respondents to the study, besides allowing the respondents to clarify some doubts about the study object. The main data of the companies, such as the RUC ${ }^{1}$, type of industry and number of workers, were confirmed with the public information obtained on the Internet.

Of the 192 collected questionnaires, those wrongly filled out and/or incomplete were eliminated; thus, 104 valid questionnaires were obtained, which meant to achieve a response rate of $54.2 \%$. The respondents were working in different hierarchical levels in their respective companies; thus, he had 27 managers (26\%), 40 department heads (38\%), 12 supervisers (12\%), and 25 analysts (24\%). The information was collected during four weeks, taking due care to avoid significant differences between the first and the last respondent.

\subsection{Measurement instrument}

A questionnaire was designed to evaluate all the variables of the study: uncertain environment, complex environment, technical innovation, administrative innovation, and organizational characteristics. Questions about the uncertain environment, complex environment, technical innovation, administrative innovation variables, are based on concepts of different authors, but were exclusively elaborated for this investigation. For the environment, the concepts of Olson, Slater and Hult (2005), and Jaworski and 
Kohli (1993) were considered; and for the organizational innovation, the concepts of Han, Kim and Srivastava (1998), Damanpour, Szabat and Evan (1989), and Damanpour (1996) were considered.

The process of elaborating and validating the measurement instrument consisted of the following actions: a) review of the definition of each variable concept and its components, b) elaboration of the new instrument proposal, c) review of the questionnaire by a survey design specialist; and d) elaboration of pilot-tests to check the reliability and validity of the instrument.

On the other hand, questions about the organizational characteristics variable were adapted from questionnaires used in previous studies, and were based on the measurement instrument of Olson, Slater and Hult (2005). To that end, the following actions were carried out: a) translation from English to Spanish of the original questionnaire by an authorized translator, b) inverse translation from Spanish to English (of the questionnaire translated in the previous step by another authorized translator, c) final review of the translations by a translator whose mother tongue is English, d) review of the questionnaire by a specialist of interpretative translation; and e) conduction of pilot-tests to evidence the reliability and validity of the instrument. For the process of English to Spanish translation and the inverse translation, the process followed by Lee (2010) was followed.

\subsection{Measurement}

In this investigation, we propose a data collection instrument (questionnaire) that collects perceptive answers about the behavior of each variable. The use of perceptive answers is very important because it allows the comparison of results among different subsectors. The proposal of the questionnaires with perceptive answers is based on the applications of Olson, Slater y Hult (2005); Tegarden et al. (2005) and Gopalakrishnan (2000). The measurement was done by using an average of the items composing each variable. Questions were presented in a
Likert scale of five points, which was used by Tegarden et al. (2005).

In the study, the environment is defined as the changes of the uncertain and complex external factors that affect the organization. The uncertain environment is defined as the frequency of change of external variables that affect the organization, such as: customers, competition, technology; and the complex environment, as the amount of external variables that affect the organization, such as: customers, competition and technology (TIDD, 2001). For each dimension of the environment, the measurement was done on the average of questions composing it. The Cronbach's Alpha coefficient in the dimensions of the environment: uncertain environment (.919) and complex environment (.867) exceed 0.7, value proposed by Klein, Astrachan and Smyrnios (2005) for the reliability analysis test.

The organizational innovation is the implementation of changes in products, services, processes, and the administrative aspects of the organization and in this study are unfold in two dimensions: technical innovation and administrative innovation. The first one consists of the implementation of changes in products, services and production processes, while the second is the implementation of changes in the organizational structure, human resources and administrative processes (DAMANPOUR, 1996). In order to measure the organizational innovation, there is no accepted proposal that encompasses all the literature gaps (ADAMS; BESSANT; PHELPS, 2006); both questions corresponding to the environment and to the organizational innovation, and their respective dimensions, were formulated by the author exclusively for this investigation. For each dimension of the organizational innovation, the measurement was done on the average of questions composing it. The Cronbach's Alpha coefficient of the dimensions of the organizational innovation: technical innovation (.907) and administrative innovation (.863)] exceeds 0.7, the value proposed by Klein, Astrachan and Smyrnios (2005) for a reliability analysis test. 
In this study, the organizational characteristics are defined as the work coordination manners that interact in an organization (FREDRICKSON, 1986), such as the formalization and the specialization. The questionnaire questions associated to this variable were taken from the survey conducted by Olson, Slater and Hult (2005).

\subsection{Validity of the environment and organizational innovation variables}

The confirmation of the hypotheses rests on the validity of the environment dimensions: uncertain environment and complex environment, and the two dimensions of the organizational innovation: technical innovation and administrative innovation. Table 1 presents a rotated factorial matrix of the environment with ten items used to build the two dimensions of the environment. The upper half of the column of factor 1 corresponds to the uncertain environment, which has five items $(.967 ; .859$; .857 ; .824; and .808). The lower half of the column of factor 2 corresponds to the complex environment, which has five items $(.817 ; .803$; .790; .786; and .783). Such items have a high degree of reasonable saturation, which confirms the unidimensional nature of the two variables, and the justification of the groups formed.

TABLE 1 - Rotated factorial matrix of the environment

\begin{tabular}{|c|c|c|}
\hline Dimensions of the Environment & Factor 1 & Factor 2 \\
\hline \multicolumn{3}{|l|}{ Uncertain environment } \\
\hline The environment is highly changeable & 0.967 & 0.193 \\
\hline Changes in the environment bring about immediate answers & 0.859 & 0.038 \\
\hline We are aware of the changes in the environment & 0.857 & 0.074 \\
\hline Advantageous decisions for changes in the environment & 0.824 & 0.171 \\
\hline Changes in the environment bring about opportunities & 0.808 & 0.263 \\
\hline \multicolumn{3}{|l|}{ Complex environment } \\
\hline Amount of variables that affect new products and services & 0.215 & 0.817 \\
\hline Amount of changes of the environment that represent threats & -0.006 & 0.803 \\
\hline Amount of variables the company is aware of to control & 0.193 & 0.790 \\
\hline Amount of environment changes that bring about opportunities & 0.243 & 0.786 \\
\hline Amount of variables that affect decisions & 0.058 & 0.783 \\
\hline Percentage of variance & 48.25 & 23.67 \\
\hline
\end{tabular}

Extraction Method: Maximum Likelihood.

Items that are inside the box have high reasonable saturation.

Source: the authors

In regard the validity of the dimensions comprehended by the organizational innovation, a factor analysis with a varimax rotation was carried out. Table 2 shows the rotated factorial matrix of the organizational innovation with ten items used to build the two dimensions of the organizational innovation: technical innovation and administrative innovation. The upper half of the column of factor 1 corresponds to the technical innovation, which has five items $(.891 ; .862 ; .843 ; .834$; and .832$)$. The lower half of the column of factor 2 corresponds to the administrative innovation, which has five items (.897; .846; .841;.717; and .702). Such items confirm the unidimensional nature of the two variables, and the justification of the groups formed. 
TABLE 2 - Rotated factorial matrix of the organizational innovation

\begin{tabular}{|c|c|c|}
\hline Dimensions of the organizational innovation & Factor 1 & Factor 2 \\
\hline \multicolumn{3}{|l|}{ Technical innovation } \\
\hline Improvement of work methods and techniques & 0.891 & 0.092 \\
\hline Improvement of products and/or services design & 0.862 & 0.001 \\
\hline Improvement of automated systems & 0.843 & 0.032 \\
\hline Improvement of production processes & 0.834 & 0.112 \\
\hline Improvement of processes incorporating new technology & 0.832 & -0.009 \\
\hline \multicolumn{3}{|l|}{ Administrative innovation } \\
\hline Change of work positions & -0.107 & 0.897 \\
\hline Change of organizational structure & -0.053 & 0.846 \\
\hline Change of functions of work positions & 0.064 & 0.841 \\
\hline Increase of changes of work positions & 0.106 & 0.717 \\
\hline Change of administrative work rules & 0.178 & 0.702 \\
\hline Percentage of variance & 48.25 & 23.67 \\
\hline
\end{tabular}

Extraction Method: Maximum Likelihood.

Items that are inside the box have high reasonable saturation.

Source: the authors

To comply with the assumptions of the multi variant analysis, all the variables of this study accomplish the normality test through the Kolomogorov-Smirnov statistic test, which tells us that the sample comes from a population with normal distribution. Furthermore, the variables accomplish the homoscedasticity test through the Levene statistic test, which shows us that the variances of the studied groups are homogeneous.

\section{RESULTS}

\section{I Environment and organizational innovation}

The $\mathrm{H} 1$ hypothesis suggests that the bigger changes in the environment are, without taking into consideration whether the environment is uncertain or complex, the more organizational innovation activities are created. Table 3 shows that this relations is positive and significant $(\beta=.462 ; \mathrm{p}<0.05)$, for what the $\mathrm{H} 1$ hypothesis is favorably sustained.

The hypotheses $\mathrm{H} 2 \mathrm{a}$ and $\mathrm{H} 2 \mathrm{~b}$ suggest that $\mathrm{n}$ increase of the environment uncertainty generates an increase of the technical innovation and the administrative innovation, respectively. Table 3 shows that such relations are partially sustained, because the parameter of the uncertain environment in the case of technical innovation $(\mathrm{H} 2 \mathrm{a})$ is positive and significant $(\beta=.446$; $\mathrm{p}<0.05)$; on the other hand, against the prediction, the parameter estimated for the uncertain environment ( $\mathrm{H} 2 \mathrm{~b})$ is not statistically significant for the administrative innovation $(\beta=$ n. s.). The hypothesis $\mathrm{H} 2 \mathrm{a}$ is favorably sustained, while the $\mathrm{H} 2 \mathrm{~b}$ is not.

The hypotheses $\mathrm{H} 3 \mathrm{a}$ and $\mathrm{H} 3 \mathrm{~b}$ suggest that $\mathrm{n}$ increase of the environment complexity generates an increase of the technical innovation and the administrative innovation, respectively. Table 3 shows that such hypotheses are fully sustained, because the parameter of the complex environment in the case of technical innovation $(\mathrm{H} 3 \mathrm{a})$ is positive and significant $(\beta=.434$; $\mathrm{p}<0.05)$, and the parameter estimated for the complex environment in the case of the administrative innovation ( $\mathrm{H} 3 \mathrm{~b}$ ) is also statistically positive and significant $(\beta=.296 ; \mathrm{p}<0.05)$. 
TABLE 3 - Statistic results of the environment-innovation model

\begin{tabular}{|c|c|c|c|}
\hline \multicolumn{4}{|c|}{ Environment } \\
\hline Dependent variable & $\beta$ & $\mathrm{R}^{2}$ & $\mathrm{~F}$ \\
\hline Innovation & $.462(* *)$ & 0.22 & $28.10(* *)$ \\
\hline \multicolumn{4}{|c|}{ Uncertain environment } \\
\hline Dependent variable & $\beta$ & $\mathrm{R}^{2}$ & $\mathrm{~F}$ \\
\hline Technical innovation & $.446(* *)$ & 0.18 & $22.35\left(^{(* *)}\right.$ \\
\hline Administrative innovation & n.s. & n.s. & n.s. \\
\hline \multicolumn{4}{|c|}{ Complex environment } \\
\hline Dependent variable & $\beta$ & $\mathrm{R}^{2}$ & $\mathrm{~F}$ \\
\hline Technical innovation & $.434(* *)$ & 0.16 & $19.77\left(^{(* *)}\right.$ \\
\hline Administrative innovation & $.296(* *)$ & 0.07 & $7.26(* *)$ \\
\hline \multicolumn{4}{|c|}{$\left(^{*}\right) \mathrm{p}<.10 ;\left({ }^{* *}\right) \mathrm{p}<.05 ;$ n.s. $=\mathrm{p}>.10$} \\
\hline $\mathrm{N}=104$ questionnaires & & & \\
\hline
\end{tabular}

Source: the authors

\subsection{Organizational characteristics as the moderator of the relation between the environment and the organizational innovation}

The hypothesis H4a suggests that the organizational characteristics variable moderates the relation between the environment and the technical innovation To obtain the results, a product of the environment variables (independent variable) and the organizational characteristics (proposed moderator variable) was defined, in order to represent the interaction between both variables. A three-step hierarchical regression analysis was done for the organizational characteristics moderator, considering the technical innovation as a dependent variable. The conceptual explanation of the moderator variable is observed in the studies of Barón and Keny (1986), and the solution by means of the hierarchical regression process to analyze a moderator can be observed in the studies of Quiles et al. (2006). Prior to conducting the statistic calculations, the variables were standardized (converted in $\mathrm{Z}$ scores) to reduce the potential multicollinearity (QUILES et al., 2006). The statistic results are shown in Table 4.

In step 1 of the regression analysis, the environment variable was introduced, and which had a high significance $(b=.66 ; p<0.05)$. In step 2, the organizational characteristics variable was added; in this step, the environment variable reached significance $(b=.51 ; \mathrm{p}<0.05)$, and the organizational characteristics variable also reached a high significance $(b=.36 ; \mathrm{p}<0.05)$. In step 3, the interaction of the environment and organizational characteristics (moderator variable) variables was introduced, but no significant results were obtained. Therefore, the H4a hypothesis is not demonstrated.

The hypothesis $\mathrm{H} 4 \mathrm{~b}$ suggests that the organizational characteristics variable moderates the relation between the environment and the administrative innovation. To obtain the results, a product of the environment variables (independent variable) and the organizational characteristics (proposed moderator variable) was defined, in order to represent the interaction between both variables. A three-step hierarchical regression analysis was done for the organizational characteristics moderator, considering the administrative innovation as a dependent variable. Results are shown in Table 5.

In step 1 of the regression analysis, the environment variable was introduced, which have significance $(b=.26 ; p<0.10)$. In step 2 , the organizational characteristics variable was introduced; in this step, the environment variable reached high significance $(b=.32 ; \mathrm{p}<0.05)$, while the organizational characteristics variable 
reached significance $(b=-.13 ; \mathrm{p}<0.10)$. In step 3 , the interaction between the environment and organizational characteristics (moderator variable) variables was introduced, and high significant results were obtained $(\mathrm{b}=.41 ; \mathrm{p}<0.05)$; in this case the interaction between the moderator variable and the predicting variable was associated to a significant increase of the explained variance of the administrative innovation $(\triangle \mathrm{F}=7.01$; $\mathrm{p}<.05)$. Therefore, the H4b hypothesis is sustained.

TABLE 4 - Hierarchical regression analysis for the organizational characteristics moderator, with the technical innovation as a dependent variable

\begin{tabular}{|c|c|c|c|c|c|}
\hline Variables & $\beta$ & $\mathbf{R}^{2}$ & $\Delta \mathbf{R}^{2}$ & $\mathbf{F}$ & $\Delta \mathbf{F}$ \\
\hline Step 1 & & 0.256 & 0.256 & $35.13(* *)$ & $35.13\left({ }^{* *}\right)$ \\
\hline Environment & $.66(* *)$ & & & & \\
\hline Step 2 & & 0.364 & 0.108 & $28.91(* *)$ & $17.14\left({ }^{* *}\right)$ \\
\hline Environment & $.51(* *)$ & & & & \\
\hline Organizational characteristics & $.36\left({ }^{* *}\right)$ & & & & \\
\hline Step 3 & & 0.380 & 0.016 & $\left.20.41{ }^{(* *}\right)$ & 2.35 (n.s.) \\
\hline Environment ${ }^{*}$ Organizational characteristics & n.s. & & & & \\
\hline
\end{tabular}

Dependent variable: Technical innovation

$\left(^{*}\right) \mathrm{p}<.10 ;\left({ }^{* *}\right) \mathrm{p}<.05 ;$ n.s. $=\mathrm{p}>.10$

$\mathrm{N}=104$ questionnaires

Source: the authors

TABLE 5 - Hierarchical regression analysis for the organizational characteristics moderator, with the administrative innovation as a dependent variable

\begin{tabular}{|c|c|c|c|c|c|}
\hline Variables & $\beta$ & $\mathbf{R}^{2}$ & $\Delta \mathbf{R}^{2}$ & $\mathbf{F}$ & $\Delta \mathbf{F}$ \\
\hline Step 1 & & 0.036 & 0.036 & $3.85\left(^{*}\right)$ & $3.85(*)$ \\
\hline Environment & $.26(* *)$ & & & & \\
\hline Step 2 & & 0.049 & 0.012 & $2.59\left(^{*}\right)$ & $1.32(\mathrm{n} . \mathrm{s})$ \\
\hline Environment & $.32(* *)$ & & & & \\
\hline Organizational characteristics & $-.13(*)$ & & & & \\
\hline Step 3 & & 0.111 & 0.062 & $4.17(* *)$ & $7.01(* *)$ \\
\hline Environment ${ }^{*}$ Organizational characteristics & $-.41\left(^{*}\right)$ & & & & \\
\hline
\end{tabular}

Dependent variable: Technical innovation

$\left(^{*}\right) \mathrm{p}<.10 ;\left({ }^{* *}\right) \mathrm{p}<.05 ;$ n.s. $=\mathrm{p}>.10$

$\mathrm{N}=104$ questionnaires

Source: the authors

\section{DISCUSSION AND IMPLICATIONS}

Considering the study objective of examining the relation between the environment and the organizational innovation, and of analyzing the behavior of the organizational characteristics as moderator variable of this relation, it is evidenced, through the analysis of empirical data, that there is, on one side, some evidences of the positive influence of the environment on the organizational innovation, and, on the other side, that there is a partial 
moderator influence of the organizational characteristics variable on the relation between environment and the organizational innovation.

The environment variable, without considering whether it is uncertain or complex, influences the organizational innovation, which means that the service companies take into consideration the behavior of external factors that affect the organization to conduct activities of organizational innovation; this is related to the works of: Damanpour (2010), who states that innovations are influenced by the market conditions $^{2}$; and McCrea and Betts (2008), who indicate that innovations allow companies to better respond to changes in the environment. In the analyses of the environment dimensions, we found out that the uncertain environment has a high significance for the application of technical innovations; however, the same does not occur in the case of the administrative innovation. This means that the most changes and uncertainty the companies perceive in the behavior of customers, competitors and technology, the more priority they will give to the implementation of changes in products/services, processes and methods of production, before changing the organizational structure, human resources and administrative processes. This result partially confirms the statement of Tidd (2001).

In the complex environment, results indicate that this facilitates the implementation of two types of innovation, technical and administrative, which means that the perception of the magnitude or the higher number of customers, competitors and technology will push the implementation both of technical and administrative innovations; in any case, changes will be implemented in products/services, processes and methods of production, as well as in the organizational structure, human resources and administrative processes. This result confirms the statement of Tidd (2001).

The moderator influence of the organizational characteristics variable is not significant in the relation between the environment and technical innovation, which presupposes that when service companies implement a technical innovation, they take into consideration the environment behavior, but do not consider the organizational characteristics variable (formalization and specialization) to make this relation stronger; in any case, they focus more on the implementation of technical innovations (products/services, production processes and methods).

The moderator influence of the organizational characteristics variable is significant in the relation between the environment and the administrative innovation, which presupposes that service companies strengthen their relation with the environment when implementing an administrative innovation (changes in the organizational structure, human resources and administrative processes) with the intervention of the organizational characteristics variable (formalization and specialization).

To the executives and/or businessmen, the perception of uncertainty in the environment results in prioritizing technical innovations, but no the administrative ones. This is a proposal that should be reformulated, because the balanced adoption of a technical innovation and an administrative innovation is more effective in the organization than the implementation of only one of them (DAMANPOUR; SZABAT; EVAN, 1989); regarding this proposal, Damanpour (2010) states that the types of innovation are not necessarily independent, and that they are interrelated, and therefore their exploration should be continued. The perception of the complexity or magnitude of the environment results in both types of innovation: technical innovations promote the organizational effectiveness, while administrative innovations are necessary to obtain a balance between the social structure and the technical system of the organization (DAMANPOUR; SZABAT; EVAN, 1989). The study results reinforce the proposal that companies should consider the importance of the administrative innovation as a complement of the technical innovation, especially when the environment is perceived as uncertain. 


\section{LIMITATIONS AND SUGGESTIONS FOR FURTHER INVESTIGATIONS}

There are various aspects not addressed in this study. The investigation is oriented towards the exploration of what happens in the service sector. This means that the results can only be generalized for this sector, but not necessarily for each subsector: banking, insurances, commerce, transports, technology, telecommunications, education, tourism, among others. This proposal agrees with Zhou, Yim and Tse (2005), who state that the impact of innovations is different in each type of market. Crossan and Apaydin (2010), in turn, suggest that new studies should propose different types of innovation in different sectors of the industry; and that is why we suggest that future studies should examine the importance of the technical innovation and of the administrative innovation in other sectors, such as manufacturing, for instance.

The conclusions of this study were formulated based on the analysis of the information perceived obtained through questionnaires, and no quantitative data were used. The measurement results were based on perceptions which could had been influenced by some kind of bias, considering that the perception of magnitudes as "very much" or "little", "bigger" or "smaller" can vary according to the subsector, the company age, the hierarchical position occupied by the interviewee, among other factors. Future studies should examine the relation between the environment and the organizational innovation, taking into consideration quantitative data.

The period between the innovation implementation and its impact on the organizational performance can vary in each subsector. For instance, in banks the perception of the innovation effect on the performance is immediate in comparison to other subsectors, such as commerce, education and others, which results are perceived at the medium term (HAN; KIM; SRIVASTAVA, 1998). In the future, studies should take into consideration samples of a single subsector.

\section{NOTA}

1. Single taxpayer registry, is a numeric code that identifies the company for tax purposes.

2. In this study the market is an external variable found in the environment.

\section{REFERENCES}

ADAMS, R.; BESSANT, J.; PHELPS R. Innovation management measurement: a review. International Journal of Management Reviews, Oxford, v. 8, n. 1, p. 21-47, Mar. 2006.

ALMIRALL, E.; CASADESUS-MANASELL, R. Open versus closed innovation: a model of discovery and divergence. Academy of Management Review, Briarcliff Manor, v. 35, n. 1, p. 27-47, Jan. 2010.

BALDWIN, C.; CLARK, K. Design rules: the power of modularity. Cambridge: MIT Press, 2000 .

BARKEMA, H.; BAUM, J.; MANNIX, E. Management challenges in a new time. Academy of Management Journal, New York, v. 45, n. 5, p. 916-930, Oct. 2002.

BARÓN, R.; KENNY, D. The moderatormediator variable distinction in social psychological research: conceptual, strategic, and statistical considerations. Journal of Personality and Social Psychology, Washington, D.C., v. 51, n. 6, p. 1173-1182, Dec. 1986.

CROSSAN, M.; APAYDIN, M. A Multidimensional framework of organizational innovation: a systematic review of the literature. Journal of Management Studies, Oxford, v. 47, n. 6, p. 1154-1191, Sept. 2010.

DAFT, R. Organization theory and design. 8th ed. St. Paul, MN: West Publishing, 2004.

D'ALVANO, L.; HIDALGO, A. Innovation management techniques and development degree 
of innovation process in service organizations. R\&D Management, [S. 1.], v.42, n.1, p. 60-70, Jan. 2012.

DAMANPOUR, F. An integration of research findings of effects of firm size and market competition on product and process innovations. British Journal of Management, Oxford, v. 21, n. 4, p. 996-1010, Dec. 2010.

- Organizational complexity and innovation: developing and testing multiple contingency models. Management Science, Linthicum, v. 42, n. 5, p. 693-716, May 1996.

Organizational innovation: a meta analysis of effects of determinants and moderators. Academy of Management Journal, New York, v. 34, n. 3, p. 555-590, Sept. 1991.

; ARAVIND, D. Managerial innovation: conceptions, processes, and antecedents, Management and Organization Review, [Carlton], v. 8, n. 2, p. 423-454, July 2012.

; EVAN, W. Organizational innovation and performance: the problem

of organizational lag. Administrative Science Quarterly, Ithaca, v. 29, n. 3, p. 392-402, Sept. 1984.

; SCHNEIDER, M. Characteristics of innovation and innovation adoption in public organizations: assessing the role of managers. Journal of Public Administration Research and Theory, Oxford, v. 19, n. 3, p. 495-522, July 2009.

; SZABAT, K.; EVAN, W. The relationship between types of innovation and organizational performance. Journal of Management Studies, Oxford, v. 26, n. 6, p. 587-602, Nov. 1989.

; WALKER, R.; AVELLANEDA, C. Combinative effects of innovation types and organizational performance: a longitudinal study of service organizations. Journal of Management Studies, Oxford, v. 46, n. 4, p. 650-675, June 2009.
DECANIO, S.; DIBBLE, C.; AMIR-ATEFI, $\mathrm{K}$. The importance of organizational structure for the adoption of innovations. Management Science, Linthicum, v. 46, n. 10, p. 1285-1299, Oct. 2000.

DUNCAN, R. Characteristics of organizational environments and perceived environmental uncertainty. Administrative Science Quarterly, Ithaca, v. 17, n. 2, p. 313-327, Sept. 1972.

ETHIRAJ, S.; LEVINTHAL, D. Modularity and innovation in complex systems. Management Science, Linthicum, v. 50, n. 2, p. 159-173, Feb. 2004.

FARJOUN, M. Beyond dualism: stability and change as a duality. Academy of

Management Review, Briarcliff Manor, v. 35, n. 2, p. 202-225, Apr. 2010.

FREDRICKSON, J. The strategic decision process and organizational structure. Academy of Management Review, Briarcliff Manor, v. 11, n. 2, p. 280-297, Apr. 1986.

GALUNIC, K.; EISENHARDT, K. Architectural innovation and modular corporate forms. Academy of Management Journal, New York, v. 44, n. 6, p. 1229-1249, Dec. 2001.

GATIGNON, H. et al. A structural approach to assessing innovation: construct development of innovation locus, type, and characteristics. Management Science, Linthicum, v. 48, n. 9, p. 1103-1122, Sept. 2002.

GILBERT, C. The disruption opportunity. MIT Sloan Management Review, Cambridge, v. 44, n. 4, p. 27-32, July 2003.

GOPALAKRISHNAN, S. Unravelling the links between dimensions of innovation and organizational performance. The Journal of High Technology Management Research, [S.1.], v. 11, n. 1, 137-153, Spring 2000.

HAN, J.; KIM, N.; SRIVASTAVA, R. Market orientation and organizational performance: is 
innovation a missing link? Journal of Marketing, [S.1.], v. 62, n. 4, p. 30-45, Oct. 1998.

HENDERSON, R.; CLARK, K. Architectural innovation: the reconfiguration of existing product technologies and the failure of established firms. Administrative Science Quarterly, Ithaca, v. 35, n. 1, p. 9-30, Mar. 1990.

HILL, C.; ROTHAERMEL, F. The performance of incumbent firms in the face of radical technological innovative. Academy of Management Review, Briarcliff Manor, v. 28, n. 2, p. 257-274, Apr. 2003.

HOSKISSON, R. et al. Conflicting voices: the effects of institutional ownership heterogeneity and internal governance on corporate innovation strategy. Academy of Management Journal, New York, v. 45, n. 4, p. 697-716, Aug. 2002.

INSTITUTO NACIONAL DE ESTADÍSTICA E INFORMATICA - INEI (Perú). PBI 19922010. Lima, [2010]. Disponible en: <http://www. inei.gob.pe/.>. Acceso en: 30 abr. 2010.

PEA 2005-2008. Lima, [2008]. Disponible en: <http://www.inei.gob.pe/.>. Acceso en: 30 abr. 2010.

JAWORSKI, B.; KOHLI, A. Market orientation: antecedents and consequences. Journal of Marketing, [S.1.], v. 57, n. 7, p. 53-70, July 1993.

KATILA, R.; SCOTT, S. When does lack of resources make new firms innovative? Academy of Management Journal, New York, v. 48, n. 5, p. 814-829, Oct. 2005.

KIMBERLY, J.; EVANISKI, M. Organizational innovation: the influence of individual, organizational, and conceptual factors on hospital adoption of technological and administrative innovations. Academy of Management Journal, New York, v. 24, n. 4, p. 689-713, Dec. 1981.

KLEIN, S.; ASTRACHAN, J.; SMYRNIOS, K. The F-PEC scale of family influence: construction, validation, and further implication for theory. Entrepreneurship Theory and Practice, [S.1.], v. 29, n. 3, p. 321-339, May 2005.

LEE, R. Extending the environmentstrategy-performance framework: the roles of multinational corporation network strength, market responsiveness, and product innovation. Journal of International Marketing, Chicago, v. 18, n. 4, p. 58-73, Dec. 2010.

LI, H.; ATUAHENE-GIMA, K. Product innovation strategy and the performance of new technology ventures in China. Academy of Management Journal, New York, v. 44, n. 6, p. 1123-1134, Dec. 2001.

MAHMOOD, I.; MITCHELL, W. Two faces: effects of business groups on innovation in emerging economies. Management Science, Linthicum, v. 50, n. 10, p. 1348-1365, Oct. 2004.

; RUFIN, C. Government's dilemma: the role of government in imitation and innovation. Academy of Management Review, Briarcliff Manor, v. 30, n. 2, p. 338-360, Apr. 2005.

MILLER, D. Strategy making and structure: analysis and implications for performance. Academy of Management Journal, New York, v. 30, n. 1, p. 7-32, Mar. 1987.

Stale in the saddle: CEO tenure and the match between organization and environment. Management Science, Linthicum, v. 37, n. 1, p. 34-52, Jan. 1991.

MCCREA, E.; BETTS, S. Failing to learn from failure: an exploratory study of corporate entrepreneurship outcomes. Academy of Strategic Management Journal, [S.1.], v. 7, n. 1, p. 111-132, Jan. 2008.

MINTZBERG, H. Structure in 5's: a synthesis of the research on organization design. Management Science, Linthicum, v. 26, n. 3, p. 322-341, Mar. 1980. 
; QUINN, J.; VOYER, J. El proceso estratégico. [S.1.]: Prentice Hall Hispanoamericana, 1997.

MISRA, R.; SHARMA, R.; KADAR, H. A case based study of the relationship between innovation and organizational structure and architecture. Journal of Academy of Business and Economics, [S.1.], v. 11, n. 4, p. 198-203, June 2011.

OLSON, E.; SLATER, S.; HULT, H. The performance implications of fit among business strategy, marketing organization structure, and strategic behavior. Journal of Marketing, [S.1.], v. 69 , n. 3, p. 49-65, July 2005.

PIL, F.; COHEN, S. Modularity: implications for imitation, innovation, and sustained advantage. Academy of Management Review, Briarcliff Manor, v. 31, n. 4, p. 995-1011, Oct. 2006.

QUILES, M. et al. Variables moderadoras y mediadoras de la relación percepción de diferencias-ansiedad intergrupal. Psicothema, Oviedo, v. 18, n. 1, p. 105-111, 2006.

RESENDE JUNIOR, P.; GUIMARÃES, T. Inovação em serviços: um estudo de caso em uma indústria do setor eletroeletrônico. Revista Brasileira de Gestáo de Negócios - RBGN, São Paulo, v. 14, n. 44, p. 293-313, jul./set. 2012.

SCHILLING, M.; STEENSMA, H. The use of modular organization form: an industry-level analysis. Academy of Management Journal, New York, v. 44, n. 6, p. 1149-1169, Dec. 2001.

SEADEN, G. et al. Strategic decisions and innovation in construction. Construction Management and Economics, London, v. 21, n. 6, p. 603-612, 2003.

SEMADENI, M. ; ANDERSON, B. The follower's dilemma: innovation and imitation in the professional services industry. Academy of
Management Journal, New York, v. 53, n. 5, p. 1175-1193, Oct. 2010.

SHEREMATA, W. Competing through innovation in network markets: strategies for challengers. Academy of Management Review, Briarcliff Manor, v. 29, n. 3, p. 359-377, July 2004.

TEGARDEN, L. et al. The engagement of employees in the strategy process and firm performance: the role of strategic goals and environment. Journal of Business Strategies, [S.1.], v. 22, n. 2, p.75-99, Sept. 2005.

TELLIS, G.; PRABHU, J.; CHANDY, R. Radical innovation across nations: the preeminence of corporate culture. Journal of Marketing, [S.l.], v. 73, n. 1, p. 3-23, Jan. 2009.

TIDD, J. Innovation management in context: environment, organization and performance. International Journal of Management Review, Oxford, v. 3, n. 3, p. 169-183, Sept. 2001.

TOIVONEN, M. Different types of innovation processes in services and their organizational implications. In: GALLOUJ, F.; DJELLAL, F. (Ed.). The handbook of Innovation and services: a multi-disciplinary perspective. Northampton: E. E. Publishing, 2010. chap. 10, p. 221-249.

TUSHMAN, M.; NADLER, D. Organizing for innovation. California Management Review, Berkeley, v. 28, n. 3, p. 74-92, Mar. 1986.

USSAHAWANITCHAKIT, P. Administrative Innovation, Technical Innovation, Competitive Advantage, Competitive Environment, and Firm Performance of Electronics Businesses in Thailand. Review of Business Research, [S.1.], v. 12, n. 1, p. 1- 10, 2012.

VAN DE VEN, A. Central problems in the management of innovation. Management Science, Linthicum, v. 32, n. 5, p. 590-607, May 1986. 
WISCHNEVSKY, J.; DAMANPOUR, F. Organizational transformation and performance: an examination of three perspectives. Journal of Managerial Issues, Pittsburgh, v. 18, n.1, p. 104-128, Spring 2006.
ZHOU, K.; YIM, C.; TSE, D. The effects of strategic orientations on technology and marketbased breakthrough innovations. Journal of Marketing, [S.1.], v. 69, n. 2, p. 42-60, Apr. 2005. 